\title{
Attitude Appraisal System in Introduction Text at French Language Thesis in Universitas Negeri Medan
}

\author{
Rabiah Adawi ${ }^{1 *}$, Andi Wete Polili ${ }^{2}$, Tengku Ratna Soraya ${ }^{3}$ \\ 1,2,3 Universitas Negeri Medan, Indonesia \\ *rabiah.adawi@yahoo.co.id
}

\begin{abstract}
This study examines the appraisal system in the text introduction to the French thesis at UNIMED by applying the Systemic Functional Linguistics theory. This study aims to describe the attitude appraisal system contained in the text introduction to the French thesis at UNIMED. The method used in this research descriptive qualitative method. The research sample was the introduction text of a French thesis at UNIMED on behalf of Ayokta Ghea M. Panjaitan, where the type of thesis is linguistics with the title analysis of the lexical meaning of eye activity in French totaling 58 pages with the highest GPA of 3.85 which has been validated native speakers named Marine Petite. Data were analyzed using the Simple Concordance Program (SCP) concordance software program using the appraisal system, namely: attitude appraisal. The results showed that the appraisal system in the French thesis introduction text at UNIMED was a paradigmatic system because the appraisal system in the French thesis text consisted of (a) Gender which consists of masculine and feminine (b) Number which consists of singular and plural.
\end{abstract}

Keywords: appraisal system, text introduction French thesis

\section{Introduction}

This research was conducted to determine the Paradigmatic System in French thesis text consisting of (a) Gender, masculine and feminine, (b) Number, which consist of: singular and plural. La langue possède un rôle important dans la vie humaine. (Language plays an important role in human life)

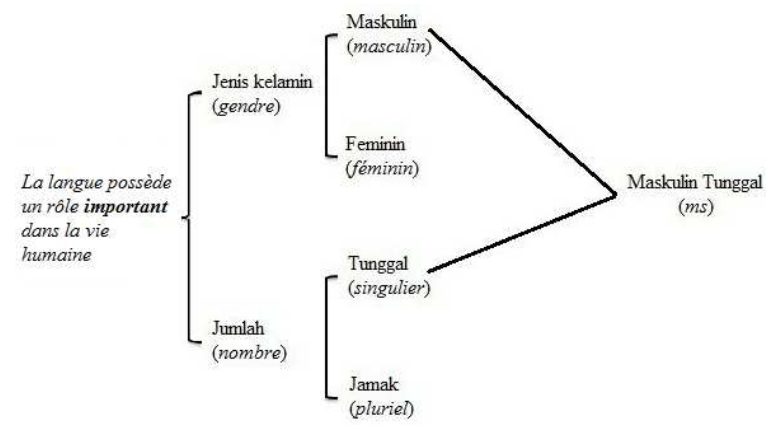

Fig 1. Language in human life 
The attitude appraisal system of the above sentence has a masculine gender and a number single. This research studies on attitude appraisal system in the text Introduction to French thesis at UNIMED. The researcher chose the research location at UNIMED because UNIMED has a French Language Study Program, a French thesis, native speaker and language laboratory facilities.

Formulation of the problem is: what attitude appraisal system is contained in the Introduction text to the French thesis at UNIMED? Research Purposes Describe the attitude appraisal system contained in the Introduction text to the French thesis at UNIMED.

\section{Appraisal System}

The theoretical basis used in this study is the Appraisal theory, which is the development of Linguistic Functional Systemic Theory in Systemic Functional Linguistics from the realm of interpersonal meaning [1,2]. This appraisal theory is an analytical tool within the scope of discourse analysis that emphasizes the positioning of readers of a text with three main domains, namely (1) attitude (2) positioning and (3) graduation, each of which becomes a single unit to analyze interpersonal meaning where in one there must be a negotiation of meaning between the writer and the reader. Paradigmatic relationships are traditionally displayed in a paradigm that describes one dimension to another [3]. The designed image referred to as (system network), a network of systems for displaying paradigmatic relationships. The names of rows and columns in the paradigm are treated as features in the system of choice, and any feature can be an input condition to other systems.

\section{Text}

Text is a functional language that is a language that performs certain tasks in a particular context, and as a unit of language users [4]. As a functional language unit in context, text is the use of language produced by people to convey the purpose of a meaningful message [5]. Text is basically a unit of meaning. Text must be viewed from two angles simultaneously, namely as a product and as a process because of its nature as a unit of meaning. As a product, text is an outcome, something that can be recorded and studied because it has a certain arrangement of texts and can be described in systematic terms. Text is also a process in the sense that text is formed through the process of choosing meaning continuously.

\section{French Grammar}

Les lettres ou les syllabes dont la désinence se compose d'indiquer selon les cas le genre, le nombre, la personne des mots et dans le verbe, le groupe, le temps et le mode [6]. Letters or syllables that have a suffix have problems with gender, number, type of words, and in verbs, groups, times, and modes.

\section{Gender}

Par genre d'un mot, on entend un caractère distinctif de ce mot, provenant de ce qu'il désigne un être mâle ou un être femelle. Il y a deux genres principaux : Le masculin, commun à tous les mots désignant des êtres mâles : homme, chat; Le féminin, commun à tous les mots désignant des êtres femelles : femme, chatte. Des raisons d'analogie, d'étymologie, d'homophonie, etc. On fait ranger dans l'un ou l'autre groupe les noms d'êtres inanimés : char, charrette. Le latin avait un troisième genre, le neutre. Il n'en est resté en français que des traces dans les adjectifs et surtout dans les pronoms : l'utile, l'agréable, cela, quoi, etc. Le neutre français se confond pour la forme et la construction avec le masculine [6]. Based on the sex of the word, we see the characteristics of a word, based on the sex, masculine or feminine. There 
are two main sexes of nouns: masculine, generally all masculin nouns are: homme, chat, feminine, generally all feminine nouns: femme, chatte.

\section{Research Method}

Descriptive method has properties and characteristics that are considered very suitable to be used for this study. Description of grammatical and semantic categories of language evaluation is done through testing the form, meaning and relationship with the elements of the text or discourse obtained specifically from the corpus of language use in French thesis text at UNIMED. Through this method with the help of concordance software programs, research data can be captured that can be used to solve research problems and achieve predetermined research goals.

This study uses a corpus as a source of research data in the form of 2 French thesis texts at UNIMED on behalf of Ayokta Ghea M. Panjaitan, with the highest GPA of 3.85 with the thesis title Analyse De Champ Lexical Des Activités Des Yeux En Français, of which 58 pages have been validated by native speakers who taught at the French Language Education Study Program at UNIMED in 2015 and also taught at the Alliance Française (AF) called Marine Petite.

Some of the reasons used as the basis for selecting the Introduction to the French thesis text above as a data source for this study are:

a. Easy access to data sources

b. Each data source can theoretically present the genre of language use in written text in the form of a different French thesis text.

c. The written text in the form of French thesis text realizes interpersonal semantic resources in a different way from the oral text.

d. Each type of text in the data source above is assumed to utilize interpersonal semantic resources differently because the two French thesis texts above are assumed to realize different contextual situations in the use of their language.

e. These two different French thesis texts have never been examined together in terms of evaluative language.

Data collection techniques carried out by collecting 2 French thesis texts at UNIMED. Then the Appraisal framework is used to find attitudes, positioning, and graduations that show the characteristics of Appraisal in the French thesis text at UNIMED. Data collection uses data search techniques by collecting French thesis text data at UNIMED. Additionally web concordance tools provided by Webcorp on the internet are used to facilitate language analysis. After the data source for each group of text is obtained and recorded in a computer. This study uses the Simple Concordance Program (SCP) concordance software program to capture, classify each lexeme of French thesis text based on Appraisal theory, namely the Attitudes, Positioning and Graduation realms, gathering and then analyzing the data. Some data collection steps are carried out as follows [7]:

1) The format of all text (html and MS Word doc) used as data sources is converted into text files (txt) format so that it can be read by SCP.

2) Each script is then scanned to collect word list data and word statistical data in the manuscript.

3) To collect lexical word data, a Stop List archive is created. 
4) Stop List is made from this word list data manually set aside words that are not included in the word with a lexical meaning, for example task words, abbreviations, names of people, and so on.

5) In the List of lexical words then observed manually to capture and collect data of words that are included in the appraisal Lexicon.

6) The appraisal lexicon is composed of examples of appraisal words that exist in each model plus a few words obtained from several text texts used as data sources in this study.

7) The appraisal Lexicon is then made a Keyword or Key Words.

8) Keywords are used in SCP to calculate and analyze the language lexicon of evaluation in each text.

The collection and processing of data ultimately results in Keywords Appraisal. This keyword is part of the data analysis tool that has been collected through the above stages.

\section{Data Analysis Technique}

The analytical method used in this research is the concordance and distribution method using the Simple Concordance Program (SCP) concordance software. Furthermore, using the Appraisal theory analysis tool there are three main domains, namely (1) the realm of attitude, (2) positioning and (3) graduation. The data analyzed is the Introduction text of the French thesis at UNIMED. Text Introduction to the French thesis at UNIMED which is used as data is distributed and interpreted to see the status and types of semantic and grammatical categories that appear in discourse texts based on Appraisal tools.

A statistical analysis is performed to see the characteristics of each text. This analysis includes analysis of lexical variations, lexical visibility, and Yule's K (text characteristics based on statistical formula to calculate the level of difficulty and repetition of words in the text) [8]. Lexical Variation $(\mathrm{VL})=$ token type ratio $\mathrm{x} 100$

Lexical flash $(\mathrm{KL})=$ ratio of lexical token type $\mathrm{x} 100$

Yule's K = statistical formula in the SCP program

\section{Results and Discussion}

Research data on the analysis of the Appraisal system in the text Introduction to the French thesis at Universitas Negeri Medan in this study were analyzed in a descriptive qualitative manner. Descriptive qualitative analysis is based on the concordance software system of the Simple Concordance Program (SCP) on the French thesis text. Through a concordance program, each word is examined in terms of form, collocation and concordance in each distribution of phrases and clauses.

By using analysis tools Appraisal theory, there are three main areas, namely (1) Attitude, (2) Positioning and (3) Graduation. The data analyzed were 2 French thesis texts at UNIMED.

\section{a. Important}

Text 1

In text 1, important lexis appears in 7th lexis. Important lexis include Attitude: Appreciation: significance: positive.

La langue possède un role important dans la vie humaine. 


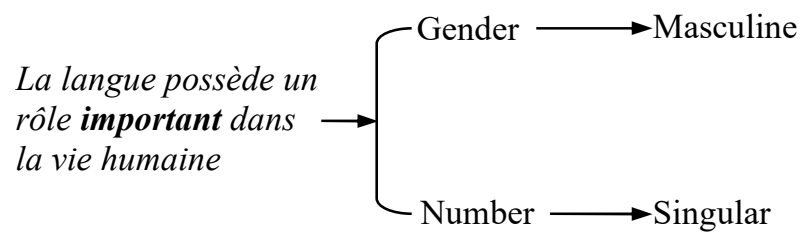

\section{b. Bien} valuation.

Lexis bien appears in 10 Lexis, includes attitude, appreciation, valuation, social Elle est importante de limiter le problème de cette recherche pour qu'elle soit claire et bien organisée.

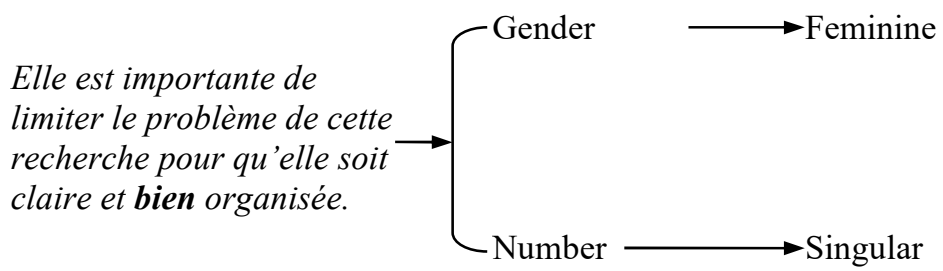

\section{c. Bon}

Lexis bon appears in 1 Lexis, includes attitude, appreciation, consideration and positive. Il n'y a pas beaucoup d'étudiants ayant une bonne capacité à informer le contenu du message à d'autres.

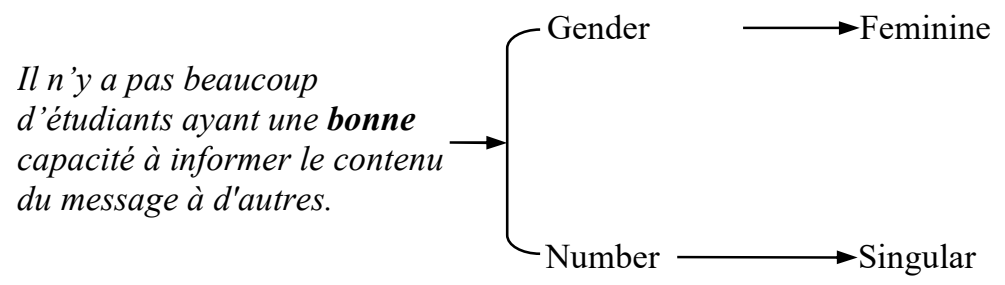

\section{Conclusion}

An analysis of the Appraisal in the Introduction of French thesis text at UNIMED shows that the Introduction of French thesis text illustrates Attitude, Establishment and Assessment in the text and context through evaluative language.

In this study conclusions can be drawn as follows: The attitude appraisal system in the text Introduction French Thesis at UNIMED is a Paradigmatic System because the attitude 
appraisal system in French thesis text consists of (a). Gender, which consists of: masculine and feminine and (b). Number, which consists of: singular and plural.

\section{References}

[1] Martin, J.R. and D. Rose. Working with Discourse. London: Continuum. (2003).

[2] Halliday, M.A.K \& Christian M.I.M. Matthiessen. Introduction to Fuctional Grammar, Third edition. London: Arnold. (2005).

[3] Martin, J.R. and White, P.R.R. The Language of Evaluation: Appraisal in English. London: Palgrave. (2005).

[4] Halliday, M.A.K. and Ruquiya Hasan. Language Context and Text: Aspect of Language in a Social Semiotic Perspective. Victoria: Deak in University Press. (1985).

[5] Widdowson, H.G. Discourse Analysis. Oxford: Oxford University. (2007).

[6] Calvet, J et Chompret, C. Grammaire Française. Paris J. De Gigord, Editeur Rue Cassette, 15. (2010).

[7] Sumarsih. Penggambaran Sikap, Pendirian, Dan Penilaian Dalam Teks Dan Konteks Melalui Bahasa Evaluatif. Dissertation. Universitas Sumatera Utara. (2009).

[8] Yule, George Udny. The Statistical Study of Literacy Vocabulary. Cambridge: CUP. (1994).

[9] Suriyadi. Apraisal Dalam Teks Editorial Surat Kabar di Medan. Unpublished Dissertation. Universitas Sumatera Utara. (2014). 